\title{
Poor vessel formation in embryos from knock-in mice expressing ALK5 with L45 loop mutation defective in Smad activation
}

\author{
Fumiko Itoh ${ }^{1,8}$, Susumu Itoh ${ }^{1,8}$, Rita LC Carvalho ${ }^{2,8}$, Tomomi Adachi ${ }^{1}$, Masatsugu Ema ${ }^{3}$, Marie-José Goumans ${ }^{4,5}$, \\ Jonas Larsson ${ }^{6}$, Stefan Karlsson ${ }^{6}$, Satoru Takahashi ${ }^{3}$, Christine L Mummery $^{2,7}$, Peter ten Dijke ${ }^{5}$ and Mitsuyasu Kato ${ }^{1}$
}

Transforming growth factor (TGF)- $\beta$ regulates vascular development through two type I receptors: activin receptor-like kinase (ALK) 1 and ALK5, each of which activates a different downstream Smad pathway. The endothelial cell (EC)-specific ALK1 increases EC proliferation and migration, whereas the ubiquitously expressed ALK5 inhibits both of these processes. As ALK1 requires the kinase activity of ALK5 for optimal activation, the lack of ALK5 in ECs results in defective phosphorylation of both Smad pathways on TGF- $\beta$ stimulation. To understand why TGF- $\beta$ signaling through ALK1 and ALK5 has opposing effects on ECs and whether this takes place in vivo, we carefully compared the phenotype of ALK5 knock-in (ALK5 ${ }^{\mathrm{KI} / \mathrm{Kl}}$ ) mice, in which the aspartic acid residue 266 in the $\mathrm{L} 45$ loop of ALK5 was replaced by an alanine residue, with the phenotypes of ALK5 knock-out $\left(\mathrm{ALK}^{-/-}\right)$and wild-type mice. The ALK5 ${ }^{\mathrm{K} / \mathrm{KI}}$ mice showed angiogenic defects with embryonic lethality at E10.5-11.5. Although the phenotype of the $A L K 5^{\mathrm{KI} / \mathrm{KI}}$ mice was quite similar to that of the $A L K 5^{-1-}$ mice, the hierarchical structure of blood vessels formed in the ALK5 ${ }^{\mathrm{KI} / \mathrm{KI}}$ embryos was more developed than that in the ALK5 ${ }^{-1-}$ mutants. Thus, the L45 loop mutation in ALK5 partially rescued the earliest vascular defects in the ALK5 ${ }^{-/-}$embryos. This study supports our earlier observation that vascular maturation in vivo requires both TGF- $\beta /$ ALK1/ BMP-Smad and TGF- $\beta /$ ALK5/activin-Smad pathways for normal vascular development.

Laboratory Investigation (2009) 89, 800-810; doi:10.1038/labinvest.2009.37; published online 27 April 2009

KEYWORDS: ALK1; ALK5; endothelium; TGF- $\beta$; vasculature; yolk sac

Formation of mature blood vessels requires endothelial cell (EC) proliferation, the construction of a permanent basement membrane, and the recruitment of mural cells such as pericytes and vascular smooth muscle cells (VSMCs). Angiogenesis, the formation of new blood vessels, is controlled in two phases: the activation and the resolution phases. In the activation phase, vascular permeability and basement membrane degradation are increased, which allows ECs to proliferate, invade, and migrate into the extracellular space and form a new capillary lumen. In the resolution phase, ECs can no longer proliferate and migrate but are tightly bound to the extracellular matrix. Mesenchymal cells are then recruited onto the endothelial tube where they dif- ferentiate into pericytes or VSMCs surrounding the newly formed vessels. Multiple cytokines, including vascular endothelial growth factor, fibroblast growth factor, plateletderived growth factor, and transforming growth factor (TGF)- $\beta$, interplay with one another to regulate EC differentiation, vascular network formation, and the establishment and maintenance of vessel wall integrity. ${ }^{1,2}$

TGF- $\beta$ is a multifunctional cytokine that regulates many cellular responses, including proliferation, differentiation, migration, and apoptosis. Aberrant TGF- $\beta$ signaling is associated with tumorigenicity, cardiovascular abnormality, and anomalies in development of the gastrointestinal tract. ${ }^{3,4}$ TGF- $\beta$ initiates its signals through a heteromeric association

\footnotetext{
${ }^{1}$ Department of Experimental Pathology, Graduate School of Comprehensive Human Sciences, University of Tsukuba, Tsukuba, Ibaraki, Japan; ${ }^{2}$ Hubrecht Laboratory, Netherlands Institute for Developmental Biology, Utrecht, The Netherlands; ${ }^{3}$ Department of Anatomy and Embryology, Graduate School of Comprehensive Human Sciences, University of Tsukuba, Tsukuba, Ibaraki, Japan; ${ }^{4}$ Department of Cardiology, Heart Lung Centre, University Medical Centre Utrecht, Utrecht, The Netherlands; ${ }^{5}$ Department of Molecular Cell Biology, Leiden University Medical Center, Leiden, The Netherlands; ${ }^{6}$ Molecular Medicine and Gene Therapy, Lund Strategic Center for Stem Cell Biology and Cell Therapy, Lund University, Lund, Sweden and ${ }^{7}$ Department of Anatomy and Embryology, Leiden University Medical Center, Leiden, The Netherlands

Correspondence: Dr S Itoh, PhD, Department of Experimental Pathology, Graduate School of Comprehensive Human Sciences, University of Tsukuba, 1-1-1 Tennodai, Tsukuba, Ibaraki 305-8575, Japan. E-mail: sitoh@md.tsukuba.ac.jp

${ }^{8}$ These authors contributed equally to this work.
}

Received 28 January 2009; revised 17 March 2009; accepted 17 March 2009 
of type I and type II serine/threonine kinase receptors induced by ligand binding. The constitutively active type II receptor kinase phosphorylates the GS domain in the type I receptor, which leads to activation of the type I receptor kinase. This directly phosphorylates downstream receptorregulated Smads (R-Smads), which form heteromeric complexes with Smad4 that subsequently translocate into the nucleus where they regulate the transcription of target genes. Smad 2 and Smad3 (termed TGF- $\beta$ /activin-specific R-Smad (AR-Smad)) act downstream of activin receptor-like kinase (ALK) 4, ALK5, and ALK7, whereas Smad1, Smad5, and Smad8 (termed BMP-specific R-Smad (BR-Smad)) are phosphorylated by ALK1, ALK2, ALK3, and ALK6. ${ }^{5}$ In most cell types, TGF- $\beta$ signaling is transduced through the ubiquitously expressed TGF- $\beta$ type I receptor ALK5, whereas in ECs another type I receptor, ALK1, phosphorylates BR-Smad upon TGF- $\beta$ stimulation. ${ }^{6,7}$ The TGF- $\beta /$ ALK1 and TGF- $\beta /$ ALK5 pathways have opposite effects on EC behavior: ALK5 inhibits EC migration and proliferation, whereas ALK1 stimulates both processes. ${ }^{8}$ Using immortalized mouse embryonic endothelial cells isolated from $\mathrm{ALK}^{-1-}$ mice, ALK5 was shown to play a critical role in TGF- $\beta$ /ALK1 signaling. Thus, the two distinct TGF- $\beta$ type I receptor pathways are thought to fine-tune EC behavior. ${ }^{9}$ Recently, BMP9 and BMP10 have been reported to be specific ligands for ALK1. ${ }^{10,11}$ However, stimulation of ECs with BMP9 inhibits their migration, ${ }^{11}$ which is in direct contrast with the effect of TGF- $\beta$ /ALK1 signaling. ${ }^{8,9}$ Thus, exactly how ALK1 controls EC activation is still unclear.

Deletion of multiple molecules in the TGF- $\beta$ signal cascade (for example, TGF- $\beta 1, \mathrm{~T} \beta$ RII, ALK1, ALK5, endoglin, and Smad5) in mice has been shown to be embryonically lethal, with defective angiogenesis in the yolk sac being the primary cause of death. ${ }^{12}$ In addition, selective deletion of ALK5 and $\mathrm{T} \beta \mathrm{RII}$ in ECs and pericytes using tissue-specific Cre-loxP deleter mice has also shown embryonic lethality because of vascular defects. ${ }^{13}$ Thus, development of vasculature in vivo requires both TGF- $\beta /$ ALK1 and TGF- $\beta /$ ALK 5 pathways in ECs and TGF- $\beta$ /ALK5 signaling in pericytes.

To investigate exactly how Smads interact with ALK1 as well as the role of TGF- $\beta$ /ALK1 signaling in vascular development in mice, we generated earlier an ALK5 knock-in $\left(\mathrm{ALK} 5^{\mathrm{KI} / \mathrm{KI}}\right.$ ) mouse in which the aspartic acid residue 266 in the L45 loop of ALK5 was replaced by an alanine residue. ${ }^{13}$ The L45 loop in TGF- $\beta$ type I receptors (ALK1-7) determines the signaling specificity of TGF- $\beta$ type I receptors by specifying which R-Smad isoform is activated. ${ }^{14,15}$ It has been reported that although the ALK5 L45 mutant can retain its own kinase activity and ability to activate the JNK/p38 pathway, it can no longer catalyze Smad2 phosphorylation because it lacks the ability to bind to Smad2. ${ }^{16}$ Unlike the wild-type allele, this mutant is unable to interact with ARSmad in ECs from ALK5 knock-out $\left(\mathrm{ALK5}^{-1-}\right)$ mice but remains capable of transducing the ALK1/BR-Smad pathway on TGF- $\beta$ stimulation. ${ }^{9}$ However, in our earlier report, rather than grossly distinguished differences between the yolk sacs of $\mathrm{ALK5}^{-1-}$ and $\mathrm{ALK5}{ }^{\mathrm{KI} / \mathrm{KI}}$ embryos, ${ }^{13}$ we observed only small differences in the timing of the appearance of the phenotype. More complete understanding of the differences in phenotype between $\mathrm{ALK}^{-1-}$ and $\mathrm{ALK} 5^{\mathrm{KI} / \mathrm{KI}}$ mice should provide new insights into the mechanism of yolk sac vasculogenesis. In this study, therefore, we conducted a detailed analysis and comparison of $\mathrm{ALK} 5^{\mathrm{KI} / \mathrm{KI}}$ and $\mathrm{ALK} 5^{-1-}$ mice.

\section{MATERIALS AND METHODS Mice and Genotyping}

$\mathrm{ALK}^{\mathrm{KI} / \mathrm{KI} 13}$ and ALK5 ${ }^{-/-}$mice ${ }^{17}$ have been described earlier. To check the genotype of $\mathrm{ALK} 5^{\mathrm{KI} / \mathrm{KI}}$ mice, one set of polymerase chain reaction (PCR) primers $\left(5^{\prime}\right.$-ACTGCTGTTCTT CCAGAGGT- $3^{\prime}$ and $5^{\prime}$-GTGGGTGAACATCCTCATAG- $3^{\prime}$ ) was used for PCR. Genotyping of $\mathrm{ALK}^{-1-}$ mice was carried out as described earlier. ${ }^{17}$ Mice were housed in the animal facilities of the Laboratory Animal Resource Center at the University of Tsukuba under SPF conditions at constant temperature and humidity and fed a standard diet. Treatment of the mice was in accordance with the institutional guidelines of the Animal Care and Use Program of the University of Tsukuba.

\section{Immunofluorescence and Histology}

Embryos and placentas were dissected and fixed in $4 \%$ paraformaldehyde (PFA) in phosphate buffered saline (PBS) overnight. For immunofluorescence, the embryos were processed for cryosectioning as described earlier ${ }^{18}$ and sectioned at a thickness of $5 \mu \mathrm{m}$ at $-22^{\circ} \mathrm{C}$. After being blocked, the sections were incubated with anti-PECAM-1 (BD Biosciences; $1: 100)$ and anti-ey-globin (1:200) antibodies (a generous gift from Dr Atsumi $)^{19}$ or with Cy3-conjugated anti$\alpha$-smooth muscle actin (SMA) (Sigma Clone $1 \mathrm{~A} 4 ; 1: 200$ ) at $4^{\circ} \mathrm{C}$ overnight. Sections were washed three times with PBS and incubated with fluorescence-conjugated secondary antibodies at room temperature for $1 \mathrm{~h}$. Images were captured by immunofluoresence microscopy (Zeiss). For histology, the paraffin-embedded tissues were sectioned at a thickness of $2.5 \mu \mathrm{m}$, deparaffinized in xylene, and rehydrated in graded ethanol solutions. Tissue samples were stained with hematoxylin and eosin according to the standard methods.

\section{Whole-mount Immunostaining}

Embryos were fixed in 4\% PFA/PBS overnight. After being washed with PBS containing $0.2 \%$ Triton X-100 (PBST), the samples were blocked with $2 \%$ skimmed milk in PBST and incubated with anti-PECAM-1 (1:100) or anti-cleaved caspase-3 (Cell Signaling; 1:200) antibody overnight at $4^{\circ} \mathrm{C}$. After being washed, samples were incubated overnight at $4^{\circ} \mathrm{C}$ with 1:200 dilutions of the secondary antibody. Subsequently, samples were washed, and the horseradish peroxidase color reaction was carried out for $10 \mathrm{~min}$ with diaminobenzidine (SK-4100; Vector Laboratories). Images were taken using a 
stereomicroscope (model MZ FL III; Leica Microscopy Systems, Deerfield, IL, USA).

\section{In situ Hybridization}

Whole-mount in situ hybridization was performed using a dioxigenin-labeled RNA probe against arterial natriuretic factor (ANF) mRNA as described earlier. ${ }^{20}$ Antisense and sense RNA probes corresponding to nucleotides 198 to 731 of ANF (GenBank accession no. NM008725) were synthesized using SP6 and T7 RNA polymerases. The probes were visualized in dark blue with NBT/BCIP (Roche Diagnostics).

\section{India Ink Injection}

After the E9.5 embryos were dissected in PBS, India ink was immediately injected into the heart using glass injection needles made of a calibrated pipette (Drummond Scientific). After the injection, the embryos were fixed in $4 \%$ PFA overnight and then photographed.

\section{In vitro Colony Assay}

For analysis of progenitor activity, the yolk sacs from the E9.5 embryos were disaggregated in $0.08 \%$ collagenase/dispase (Roche Diagnostics) at $37^{\circ} \mathrm{C}$ for $30 \mathrm{~min}$. Cells were plated in methylcellulose medium (MethoCult M3231; Stem Cell Technologies) containing $10 \mathrm{ng} / \mathrm{ml}$ interleukin-3, $10 \mathrm{ng} / \mathrm{ml}$ erythropoietin, $10 \mathrm{ng} / \mathrm{ml}$ stem cell factor, and $50 \mathrm{ng} / \mathrm{ml}$ granulocyte colony-stimulating factor. Colony-forming unit-macrophage (CFU-M), burst-forming unit-erythroid (BFU-E), mixed colonies (Mix), and colony forming unitgranulocyte/macrophage (CFU-GM) were counted 7 days after culture. ${ }^{21}$ Colony types were scored according to the morphological criteria. ${ }^{22}$

\section{RESULTS}

\section{ALK5 ${ }^{\mathrm{KI} / \mathrm{KI}}$ Mice}

To investigate the differences between the TGF- $\beta /$ ALK1/BRSmad and TGF- $\beta /$ ALK5/AR-Smad pathways in ECs, we generated $\mathrm{ALK} 55^{\mathrm{KI} / \mathrm{KI}}$ mice carrying a single amino acid substitution in the ALK5 L45 loop; that is, the aspartic acid residue 266 is replaced by an alanine residue (ALK5 $(\mathrm{D} 266 \mathrm{~A})) .{ }^{13}$ We have shown earlier that the ALK5 (D266A) mutant did not phosphorylate AR-Smad in vitro but retained the ability to mediate the activation of the TGF- $\beta$ /ALK1/ BR-Smad pathway in ECs isolated from ALK5 ${ }^{-1-}$ embryos. ${ }^{9}$

$\mathrm{ALK}_{5} \mathrm{KI} /+$ mice were born alive and phenotypically normal, like their wild-type littermates (data not shown). Although we knew that all ALK5 ${ }^{\mathrm{KI} / \mathrm{KI}}$ embryos die between E10.5 and E11.5, ${ }^{13}$ we wanted to know how death was distributed over this time period. As shown in Table 1, there were no $\mathrm{ALK} 5^{\mathrm{KI} / \mathrm{KI}}$ embryos with beating hearts at E11.5 when heterozygous intercrosses were genotyped. On the other hand, at E10.5 nearly $23 \%$ of the living embryos were $\mathrm{ALK5}^{\mathrm{KI} / \mathrm{KI}}$ mice. At E8.5-E10.5, the expected Mendelian ratios of the $\mathrm{ALK} 5^{\mathrm{KI} / \mathrm{KI}}$ embryos were found. Similar results
Table 1 Genotype analysis of embryos isolated from ALK5 $5^{\mathrm{KI} /+}$ intercrosses

\begin{tabular}{lcccr}
\hline Age & $+/+$ & $\mathrm{KI} /+$ & $\mathrm{Kl} / \mathrm{KI}$ & Total \\
\hline E8.5 & 33 & 79 & 44 & 156 \\
E9.5 & 52 & 116 & 52 & 224 \\
E10.5 & 42 & 89 & $42(3)$ & 173 \\
E11.5 & 14 & 24 & $8(8)$ & 46 \\
Postnatal & 81 & 132 & 0 & 213
\end{tabular}

Number in parentheses indicates dead embryos.

Table 2 Genotype analysis of embryos isolated from ALK5 ${ }^{+/-}$ intercrosses

\begin{tabular}{lrccr}
\hline Age & + ++ & $+/-$ & $-/-$ & Total \\
\hline E8.5 & 7 & 20 & 7 & 34 \\
E9.5 & 48 & 99 & 44 & 191 \\
E10.5 & 18 & 28 & $18(3)$ & 64 \\
E11.5 & 4 & 15 & $5(5)$ & 24 \\
Postnatal & 40 & 67 & 0 & 107 \\
\hline
\end{tabular}

Number in parentheses indicates dead embryos.

were obtained from the intercrosses of the $\mathrm{ALK}^{+/-}$mice (Table 2).

\section{Abnormal Vascular Network Formation And Morphology In ALK5 ${ }^{\mathrm{K} / \mathrm{KI}}$ Embryos}

At E8.5, the ALK5 ${ }^{\mathrm{KI} / \mathrm{KI}}$ embryos were similar to the wild-type embryos in gross morphology (data not shown). Primitive erythropoiesis and extraembryonic vasculogenesis are normally evident in the blood island of the yolk sac at around E8-8.5. ${ }^{23}$ When yolk sacs from $\mathrm{ALK} 5^{\mathrm{KI} / \mathrm{KI}}$ and wild-type embryos were stained with anti-Ey-globin and anti-PECAM-1 antibodies, positive cells for both markers were found in the $\mathrm{ALK} 5^{\mathrm{KI} / \mathrm{KI}}$ yolk sacs (Figure 1a) and in the wild-type yolk sacs (data not shown). Thus, the development of primitive hematoblasts and angioblasts in the yolk sac was not affected by the substitution of Asp266 with Ala in the ALK5 mice. However, at E9.5, the ALK5 ${ }^{\mathrm{KI} / \mathrm{KI}}$ embryos were easily distinguishable from both the $\mathrm{ALK}^{+/+}$and the $\mathrm{ALK}^{\mathrm{KI} /+}$ embryos because their yolk sacs were dimpled and wrinkled. Compared with the wild-type embryos (Figure 1b), the ALK5 ${ }^{\mathrm{KI} / \mathrm{KI}}$ embryos showed pale bodies, enlarged pericardial sacs, and growth retardation (Figure 1c), although there was no apparent hemorrhage. Analogous phenotypes were exhibited by $\mathrm{ALK5}^{-1-}$ embryos (Figure 1d) as described earlier. ${ }^{17}$ These phenotypes are characteristic of mutant embryos with cardiovascular defects. ${ }^{24}$ To investigate the defects of the vascular system in the $A L K 5^{\mathrm{KI} / \mathrm{KI}}$ embryos, whole 

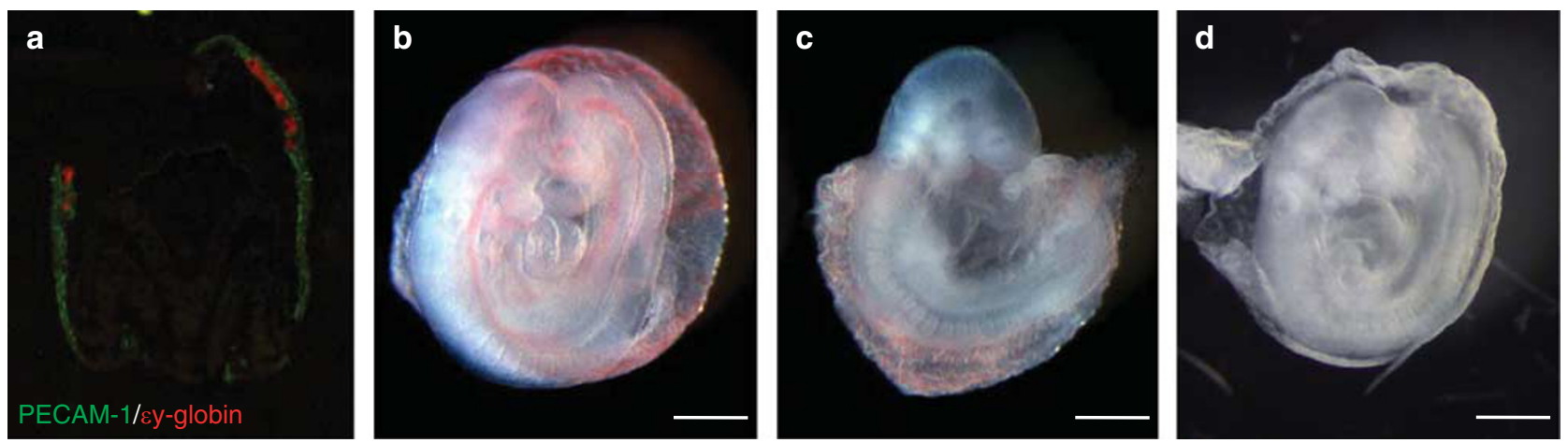

Figure 1 Phenotype of ALK5 ${ }^{\mathrm{K} / \mathrm{Kl}}$ embryo at E8.5 and E9.5. (a) Presence of hematoblasts and angioblasts in the blood island. Transverse section of the ALK5 ${ }^{\mathrm{KI} / \mathrm{Kl}}$ embryo at E8.5 was stained with anti-PECAM-1 (green) and anti-ey-globin (red) antibodies. (b-d) Gross morphology of (b) the wild-type, (c) ALK5 $5^{\mathrm{K} / \mathrm{Kl}}$ and (d) $\mathrm{ALK}^{-1-}$ embryos at E9.5. Embryos from the ALK5 ${ }^{\mathrm{KI} / \mathrm{KI}}$ and $\mathrm{ALK} 5^{-/-}$mice show pericardial effusions. Scale bar: $500 \mu \mathrm{m}$.

embryos were stained with anti-PECAM-1 antibody to visualize the vasculature. There was no obvious difference in the formation of the primary capillary plexus among the $\mathrm{ALK}^{\mathrm{KI} / \mathrm{KI}} \mathrm{ALK5}{ }^{\mathrm{KI} /+}$, and wild-type embryos at E8.5 (data not shown). In the wild-type embryos, the cephalic veins in the midbrain were branched into a hierarchical vascular network at E9.5 (Figure 2a). Furthermore, the dorsal aorta (DA) and anterior cardinal vein (ACV) in the wild-type embryos were visible. The lumen of the vasculature was surrounded by PECAM-1 positive ECs (Figure $2 \mathrm{~d}$ ). In contrast, the blood vessels of the $\mathrm{ALK} 5^{\mathrm{KI} / \mathrm{KI}}$ and $\mathrm{ALK}^{-1-}$ embryos at E9.5 remained immature (Figures $2 \mathrm{~b}$ and $\mathrm{c}$ ). In addition, the $\mathrm{ACV}$ in the $\mathrm{ALK} 5^{\mathrm{KI} / \mathrm{KI}}$ embryos was faintly stained with anti-PECAM-1 antibody (Figure 2b), whereas both the DA and ACV in the ALK5 ${ }^{-1-}$ embryos were hardly visible in the whole-mount staining with anti-PECAM-1 antibody (Figure 2c). However, we could observe PECAM-1 positive cells around the DAs and ACVs in the cross sections of both the $\mathrm{ALK} 5^{\mathrm{KI} / \mathrm{KI}}$ and the $\mathrm{ALK} 5^{-1-}$ embryos even though there were fewer PECAM-1 positive cells in the $\mathrm{ALK} 5^{\mathrm{KI} / \mathrm{KI}}$ and $\mathrm{ALK} 5^{-1-}$ embryos than in the wild-type embryos (Figure 2d-f). At E9.5, there were also more somites in the $\mathrm{ALK}_{5}{ }^{\mathrm{KI} / \mathrm{KI}}$ embryos than in the $\mathrm{ALK}^{-1-}$ embryos. As TGF- $\beta$ is known to control the action of mural cells as well as that of ECs, ${ }^{13}$ we also tested whether ECs are surrounded by mural cells in DAs from both $\mathrm{ALK}^{\mathrm{KI} / \mathrm{KI}}$ and $\mathrm{ALK}^{-1-}$ embryos at E10.5. Although ECs could be seen in the DAs from both mutant embryos at E10.5, no ECs from both mutant embryos at E10.5 were covered with mural cells. Conversely, the wildtype embryo at E10.5 exhibited mural cells surrounding the ECs (Figure 2g). Thus, both mutant embryos lacked the ability to recruit mural cells around ECs in blood vessels as well.

To assess the blood flow patterns in the $\mathrm{ALK} 5^{\mathrm{KI} / \mathrm{KI}}$ embryo, India ink was injected into the ventricle of the embryo at E9.5. As shown in Figure 2h, the wild-type embryos had well defined circulation via the DA through the branchial arches.
In contrast, ink was ejected from the dilated DA in the $\mathrm{ALK} 5^{\mathrm{KI} / \mathrm{KI}}$ and $\mathrm{ALK} 5^{-1-}$ embryos because of severely impaired cardiac function and circulation (Figure $2 \mathrm{i}$ and $\mathrm{j}$ ). Abnormal circulation might have affected embryonic development so that the growth of the $\mathrm{ALK} 5^{\mathrm{KI} / \mathrm{KI}}$ and $\mathrm{ALK} 5^{-1-}$ embryos was retarded. These embryos were also stained with anti-cleaved caspase 3 antibody, a marker of apoptosis. Only a few cells expressing activated caspase 3 were detected in the wild-type embryos, whereas both the $\mathrm{ALK} 5^{\mathrm{KI} / \mathrm{KI}}$ and the $\mathrm{ALK}^{-l-}$ embryos showed increased numbers of positive cells (Figure 2k-2m).

\section{Angiogenic Defects In Yolk Sacs}

At E9.5, yolk sacs normally undergo remodeling of the vascular network with branching of vessels (Figure 3a), whereas in the $\mathrm{ALK} 5^{\mathrm{KI} / \mathrm{KI}}$ and $\mathrm{ALK} 5^{-1-}$ yolk sacs, the initial primitive vascular plexus including the large vitelline vessels was only just formed (Figure $3 \mathrm{~b}$ and $\mathrm{c}$ ). Of note were the structural differences between the $\mathrm{ALK} 5^{\mathrm{KI} / \mathrm{KI}}$ and $\mathrm{ALK}^{-1-}$ yolk sac vessels apparent at higher magnification. The primitive vasculature from the $\mathrm{ALK5}^{-1-}$ yolk sacs merged together and was composed of hyper-fused vessels (Figure 3f), whereas there were many branched and sprouting vessels (arrows) on the yolk sacs from the ALK5 ${ }^{\mathrm{KI} / \mathrm{KI}}$ embryos (Figure 3e). When we compared the area of vessels in the yolk sacs of these embryos, the ratios of the vessel area in the wild-type and $\mathrm{ALK5}^{-1-}$ yolk sacs were the smallest and the largest, respectively, because the vessels from the wild-type yolk sac had already become mature. On the other hand, the ratio of the vessel area in the $\mathrm{ALK} 5^{\mathrm{KI} / \mathrm{KI}}$ yolk sac was intermediate between these values. These results indicated that the vasculature from the $\mathrm{ALK} 5^{\mathrm{KI} / \mathrm{KI}}$ embryos was more mature than that from the $\mathrm{ALK}^{-1-}$ embryos. Histological analysis of the $\mathrm{ALK}^{-1-}$ yolk sacs at E9.5 showed expanded vessels and a few adhesion sites between the endoderm and mesoderm layers (Figure 3i). This suggested that the yolk sacs from the $\mathrm{ALK5}^{-1-}$ embryos had more disorganized vessels than those from the ALK5 ${ }^{\mathrm{KI} / \mathrm{KI}}$ embryos (Figure $3 \mathrm{~h}$ ). Taken together, the 
embryos from the $\mathrm{ALK} 5^{\mathrm{KI} / \mathrm{KI}}$ and $\mathrm{ALK} 5^{-/-}$mice had normal vasculogenesis with endothelial differentiation. However, angiogenesis was defective in both the ALK5 $\mathrm{KI} / \mathrm{KI}$ and
$\mathrm{ALK}^{-1-}$ yolk sacs notwithstanding the fact that angiogenesis was slightly more advanced in the $\mathrm{ALK} 5^{\mathrm{KI} / \mathrm{KI}}$ yolk sac than in the $\mathrm{ALK5}^{-1-}$ yolk sac.
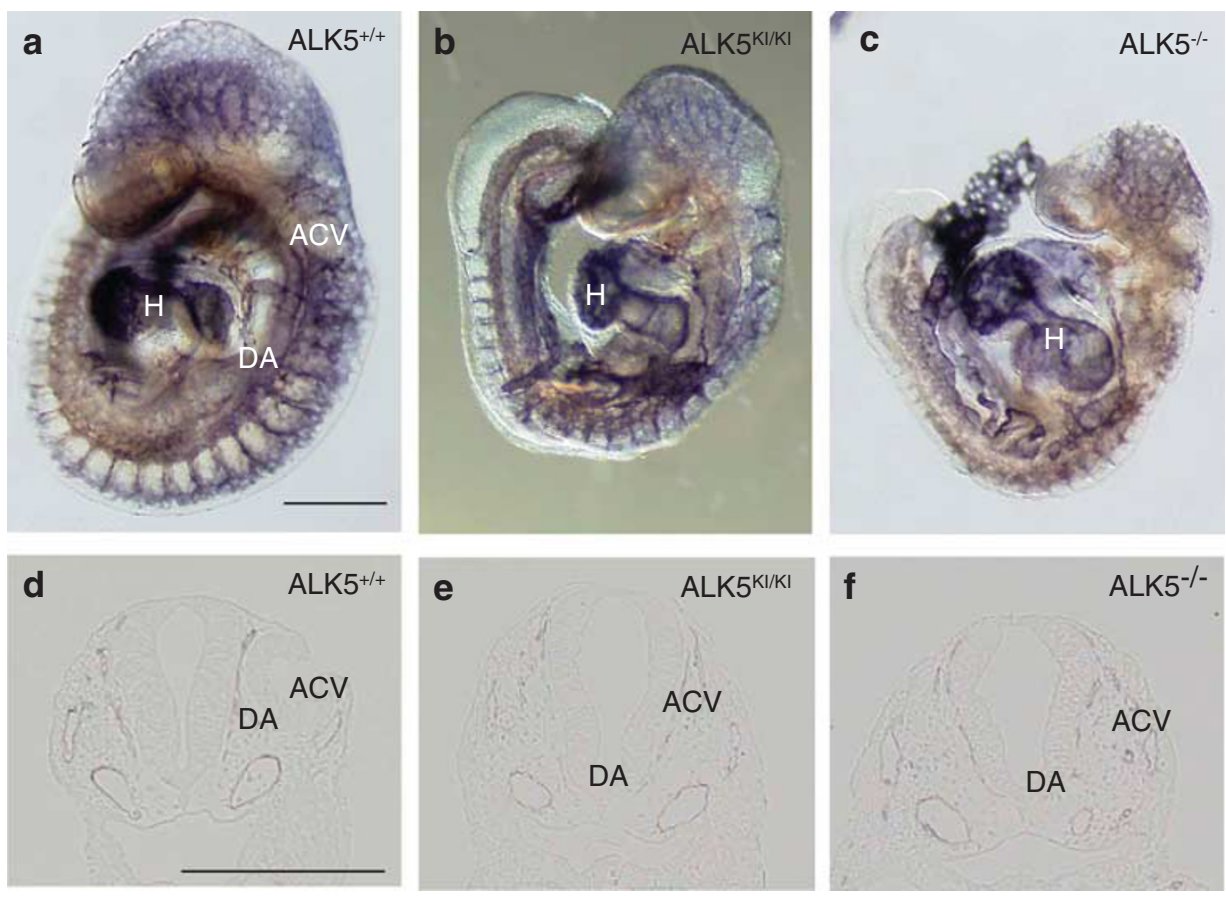

g

PECAM-1

SMA
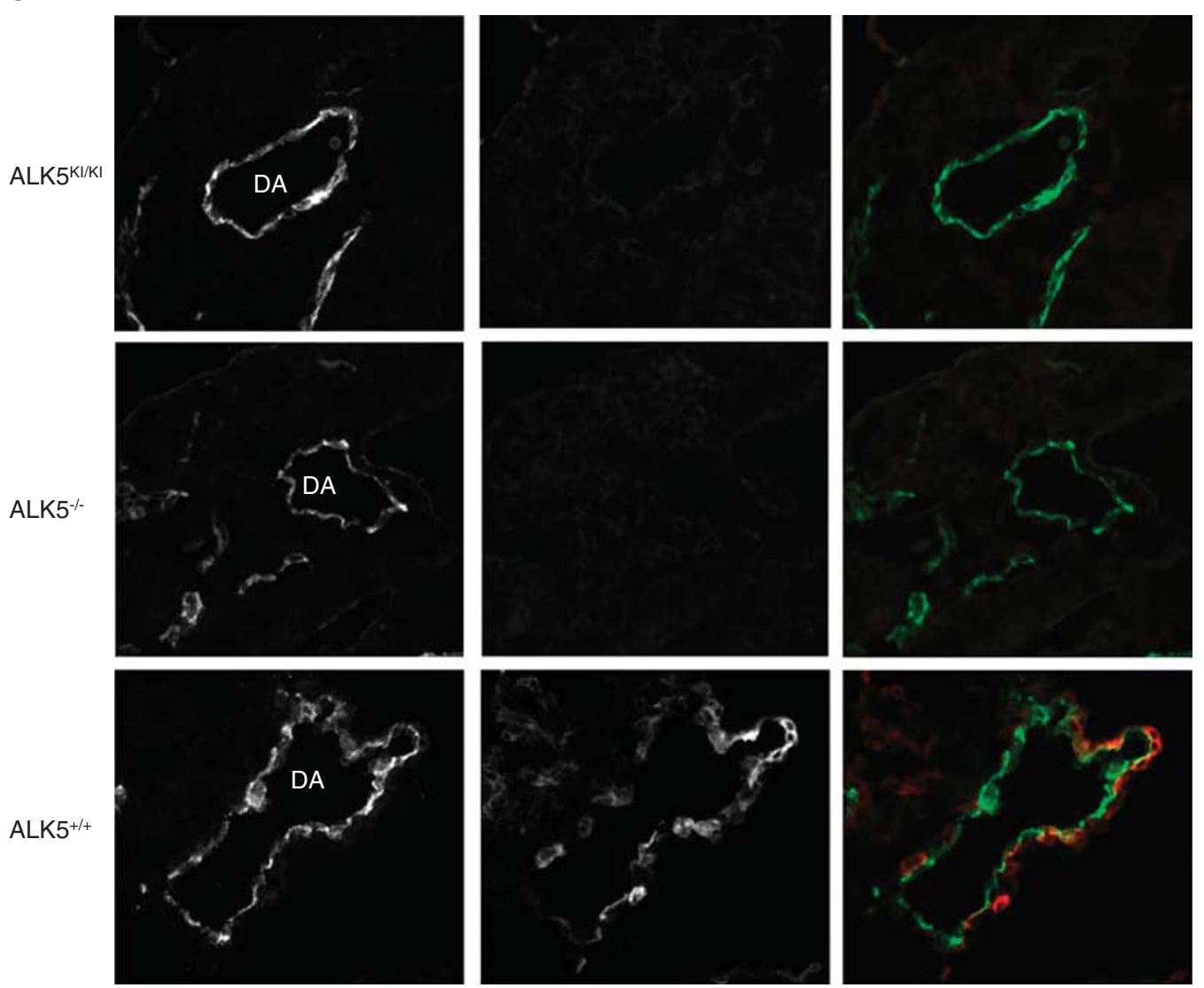


\section{Angiogenic Defects in the Placenta}

Angiogenic deficiency in the yolk sac is often accompanied by defects in the placental vasculature. Adequate vasculature in the placenta is indispensable for gas and nutrient exchange between the fetus and mother. ${ }^{25}$ Placental development is initiated by fusion of the chorionic plate with the allantois at E8.5. The chorionic trophoblast, with its associated fetal blood vessels, then undergoes extensive branching to form the placental labyrinth layer. ${ }^{25}$ We observed chorioallantoic fusion and development of the umbilical cord in the $\mathrm{ALK}^{\mathrm{KI} / \mathrm{KI}}$ embryos at E9.5 (Figure 4a), as well as in the wild-type embryos at E9.5 (data not shown). However, the allantois in the $\mathrm{ALK} 5^{\mathrm{KI} / \mathrm{KI}}$ embryos at E10.5 did not mature to form a thick umbilical cord (Figure 4b). In addition, stagnating blood was observed in the umbilical cord in the ALK5 $5^{\mathrm{KI} / \mathrm{KI}}$ embryos at E10.5 (Figure 4b). We therefore anticipated that the vasculature in the placenta of the $\mathrm{ALK} 5^{\mathrm{KI} / \mathrm{KI}}$ embryos might be incomplete. To explore this, we compared placental sections of the wild-type, ALK5 ${ }^{\mathrm{K} / \mathrm{KI}}$ and $\mathrm{ALK} 5^{-/-}$embryos. Fetal erythrocytes contain nuclei that stain with hematoxylin. Thus, fetal vessels (blue arrows) can be distinguished from maternal vessels that include eosin-positive erythrocytes (red arrows). At E10.5, the placentas from the $\mathrm{ALK} 5^{\mathrm{KI} / \mathrm{KI}}$ and $\mathrm{ALK}^{-1-}$ embryos were still of the expected size but
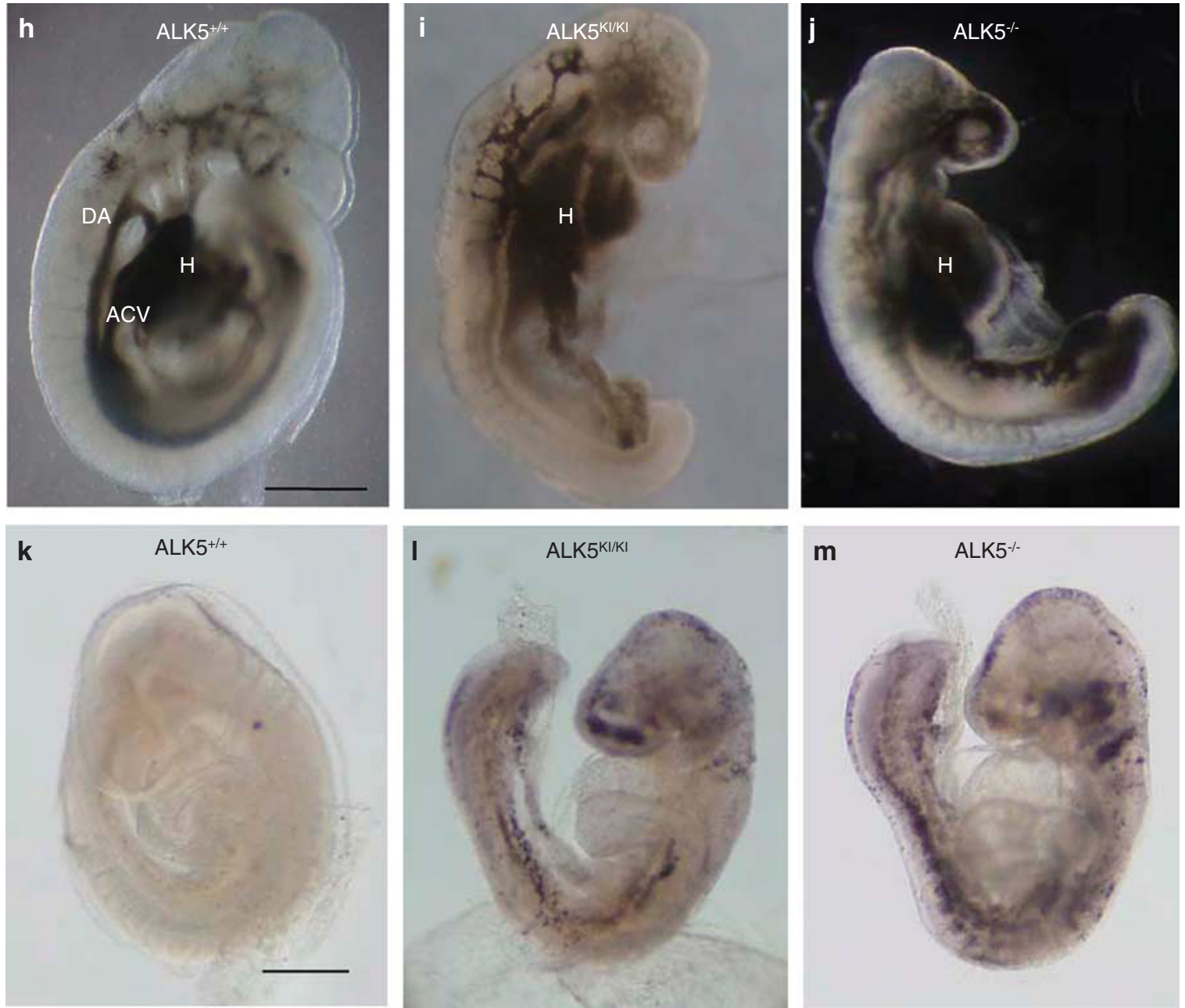

Figure 2 Continued.

Figure 2 Defects in vascular remodeling in ALK5 ${ }^{\mathrm{K} / \mathrm{KI}}$ embryos. (a-c) Staining of whole embryos at E9.5 with anti-PECAM-1 antibody. (d-f) Cross-sections of embryos at E9.5 after staining with anti-PECAM-1 antibody. (g) Transverse sections of embryos at E10.5 were stained with anti-PECAM-1 (green) and anti- $\alpha$-SMA (red) antibodies. The sizes of the aortas in both mutants were small because of their growth retardation. (h-j) Whole embryos at E9.5 after the injection of India ink into the cardiac ventricle. (k-m) Whole-mount immunostaining of the embryos at E9.5 with anti-cleaved caspase3 antibody: (a, $\mathbf{d}, \mathbf{h}, \mathbf{k}$ ) wild-type embryos; (b, e, i, I) ALK5 ${ }^{\mathrm{K} / \mathrm{Kl}}$ embryos; $(\mathbf{c}, \mathbf{f}, \mathbf{j}, \mathbf{m})$ ALK5 ${ }^{-1-}$ embryos. Scale bar: $500 \mu \mathrm{m}$. H, heart; DA, dorsal aorta; ACV, anterior cardinal vein. To support evidence of the aberrant phenotype seen in the mutant mice, we have added the photos for whole embryos at E9.5 stained with anti-PECAM-1 antibody in Supplementary Figure 1. 

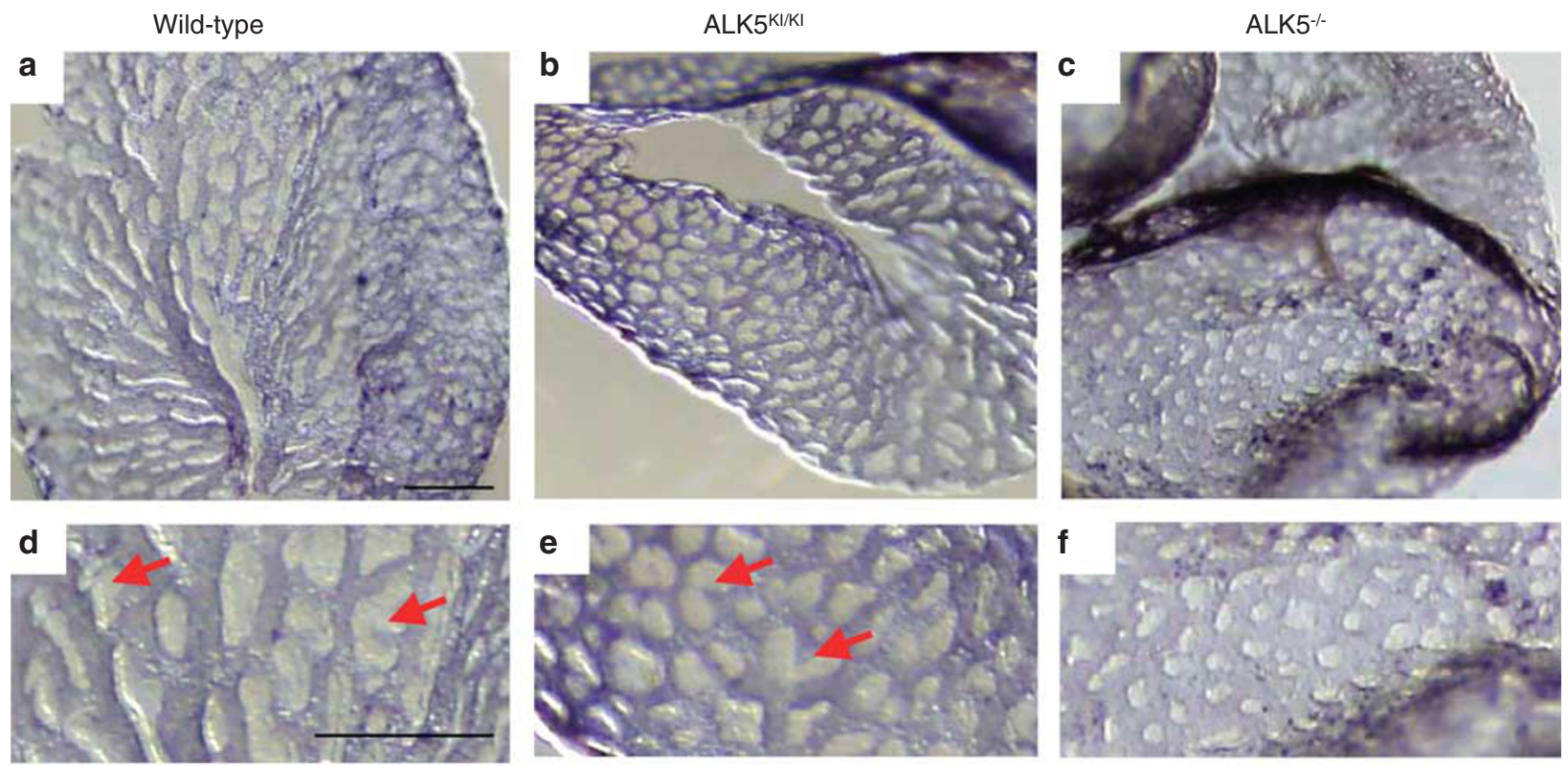

$77.06 \pm 4.26 \%$

$81.66 \pm 3.69 \%$

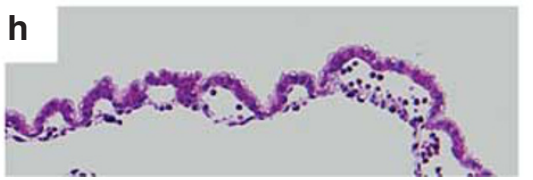

$89.20 \pm 2.01 \%$

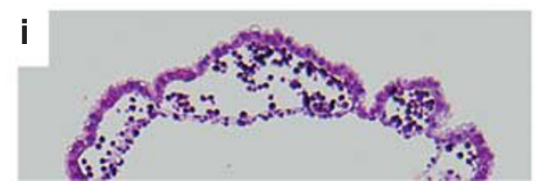

Figure 3 Defects of vascular remodeling in ALK5 ${ }^{\mathrm{KI} / \mathrm{KI}}$ yolk sacs at E9.5. (a-c) Staining of the yolk sacs with anti-PECAM-1 antibody. (d-f) Higher magnitude images of $\mathbf{a}-\mathbf{c}$. (g-i) Representative sectioned yolk sacs: (a, d, g) wild-type yolk sac; (b, e, h) ALK5 ${ }^{\mathrm{KI} / \mathrm{KI}}$ yolk sac; $(\mathbf{c}, \mathbf{f}, \mathbf{i}) \mathrm{ALK5}{ }^{-/-}$yolk sac. The values (mean \pm s.d., $n=3$ ) indicate the ratios of the vessel (PECAM-1 positive) area in the yolk sac. Supplementary Figure 2 shows other photos for the yolk sacs. Arrows indicate active sprouting vessels. Scale bar: $500 \mu \mathrm{m}$.

exhibited severe structural abnormalities (Figure $4 \mathrm{~d}$ and e). In the wild-type placentas, the fetal vessels invaded the chorionic plate to establish the labyrinthine layer with giant cells and spongiotrophoblast layers (Figure 4c). However, there was no intricate network of branching vessels from the embryos in the $\mathrm{ALK} 5^{\mathrm{K} / \mathrm{KI}}$ and $\mathrm{ALK} 5^{-1-}$ placentas. Importantly, fetal blood vessels were not detected close to the maternal blood sinuses in the ALK5 $5^{-1-}$ placentas, whereas a few fetal blood vessels approached the maternal vessels in the placentas of the ALK5 ${ }^{\mathrm{KI} / \mathrm{KI}}$ embryos (Figure $4 \mathrm{~d}$ and e).

\section{Cardiac Abnormality in ALK5 $5^{\mathrm{KI} / \mathrm{KI}}$ and ALK5 ${ }^{-1-}$ Embryos}

The heart is the first organ to form in the embryo. It is known that heart looping is initiated in the mouse at around E8.0. ${ }^{26}$ In the wild-type embryos at E9.5, heart looping was complete, whereas the $\mathrm{ALK} 5^{\mathrm{KI} / \mathrm{KI}}$ and $\mathrm{ALK5}{ }^{-1-}$ embryos at E9.5 showed withered hearts and pericardial effusions in addition to a much thinner myocardium. Furthermore, the surface of the heart in the $\mathrm{ALK}^{-1-}$ embryos looked rough (Figure 5a-c). The observation of withered hearts and pericardial effusions in the mutant embryos prompted whole-mount in situ hybridization for ANF expression. ANF is a downstream target of the early cardiac specification markers, $\mathrm{NKx} 2.5$ and GATA4. ${ }^{27,28}$ ANF expression was detected not only in the wild- type embryos (Figure 5d) but also in both mutant embryos (Figure 5e and f). Thus, cardiac abnormality in mutant embryos might not be because of defective cardiac development.

\section{Increase of Erythroid and Macrophage Colonies in Hematopoietic Progenitors Derived from Yolk Sacs in ALK5 ${ }^{\mathrm{KI} / \mathrm{KI}}$ and $\mathrm{ALK5}^{-/-}$Embryos}

As the erythroid colony-forming ability in the $\mathrm{ALK5}^{-1-}$ yolk sac has been reported to be far superior to that in the wild-type yolk sac, ${ }^{17}$ we were prompted to examine in vitro hematopoietic clonogenic progenitor formation using the yolk sacs from ALK5 ${ }^{\mathrm{KI} / \mathrm{KI}}$ and $\mathrm{ALK5}{ }^{-/-}$embryos. Like the $\mathrm{ALK}^{-1-}$ yolk sac, the numbers of erythroid-forming progenitors (BFU-E) from the $\mathrm{ALK} 5^{\mathrm{KI} / \mathrm{KI}}$ yolk sac were greatly increased compared with those from the wild-type yolk sac (Figure 6). Interestingly, more macrophage colonies (CFU$\mathrm{M})$ were observed in the yolk sacs from both mutants than in those from the wild-type embryos, although no obvious differences were detected with respect to the ability to form myeloid colonies (CFU-GM) (Figure 6). These findings suggest that the absence of blood cells from the yolk sacs of both mutant mice is not because of deficient ability to form primitive erythroid cells. However, it remains unclear why differentiation of hematopoietic progenitors to erythrocyte 

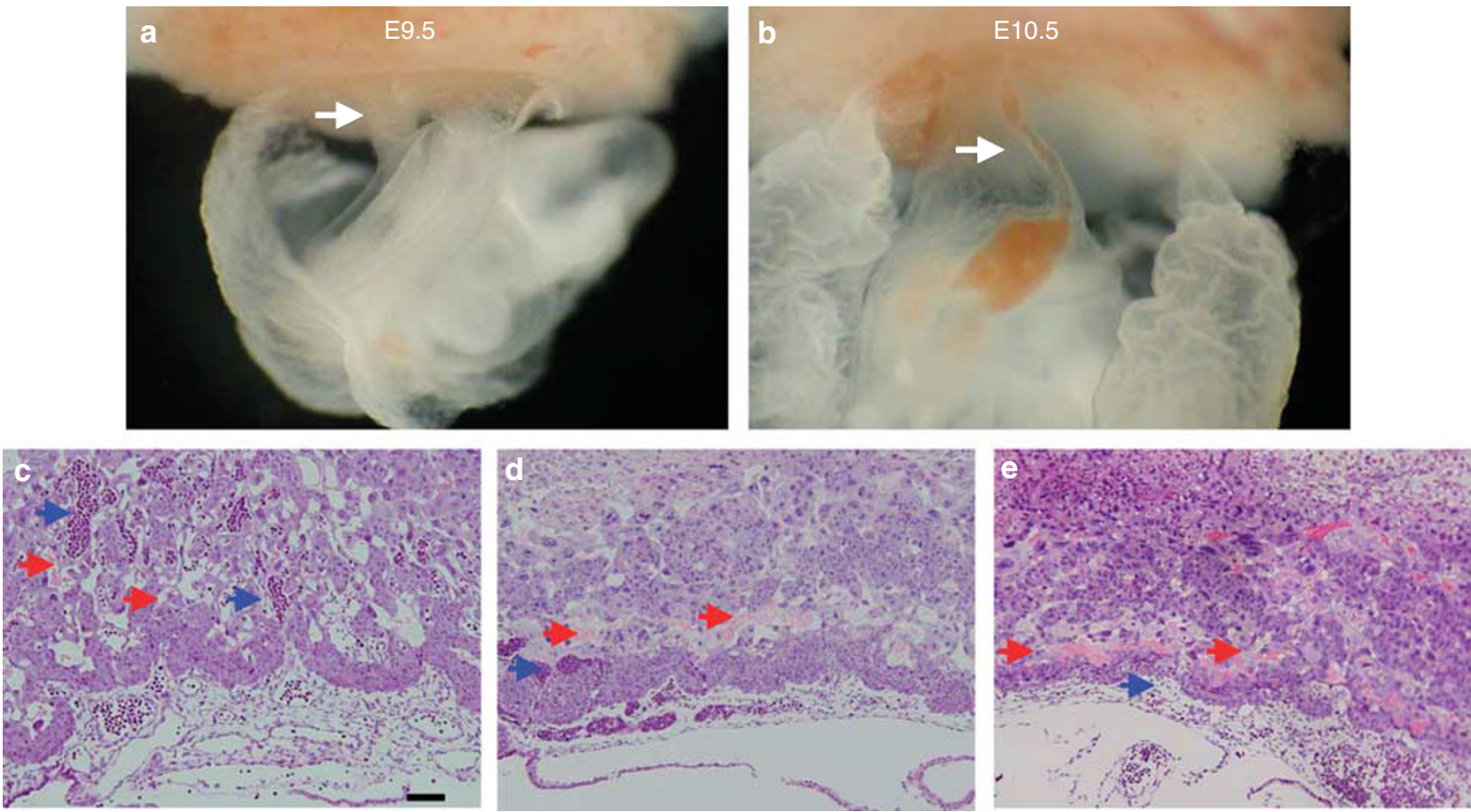

Figure 4 Labyrinthine layer architecture of ALK5 ${ }^{\mathrm{K} / \mathrm{Kl}}$ placenta. $(\mathbf{a}, \mathbf{b})$ Gross morphology of the umbilical cord between the placenta and embryo from the $\mathrm{ALK} 5^{\mathrm{K} / \mathrm{KI}}$ mice at E9.5 (a) and E10.5 (b). White arrows indicate the umbilical cords. (c-e) Section through the chorioallantoic region of the placenta from the wild-type (c), ALK5 ${ }^{\mathrm{KI} / \mathrm{KI}}(\mathbf{d})$, and ALK5 ${ }^{-1-}$ embryos (e) at E10.5. Sections were stained with hematoxylin and eosin. Red and blue arrows indicate maternal and fetal red blood cells, respectively. Scale bar: $200 \mu \mathrm{m}$.
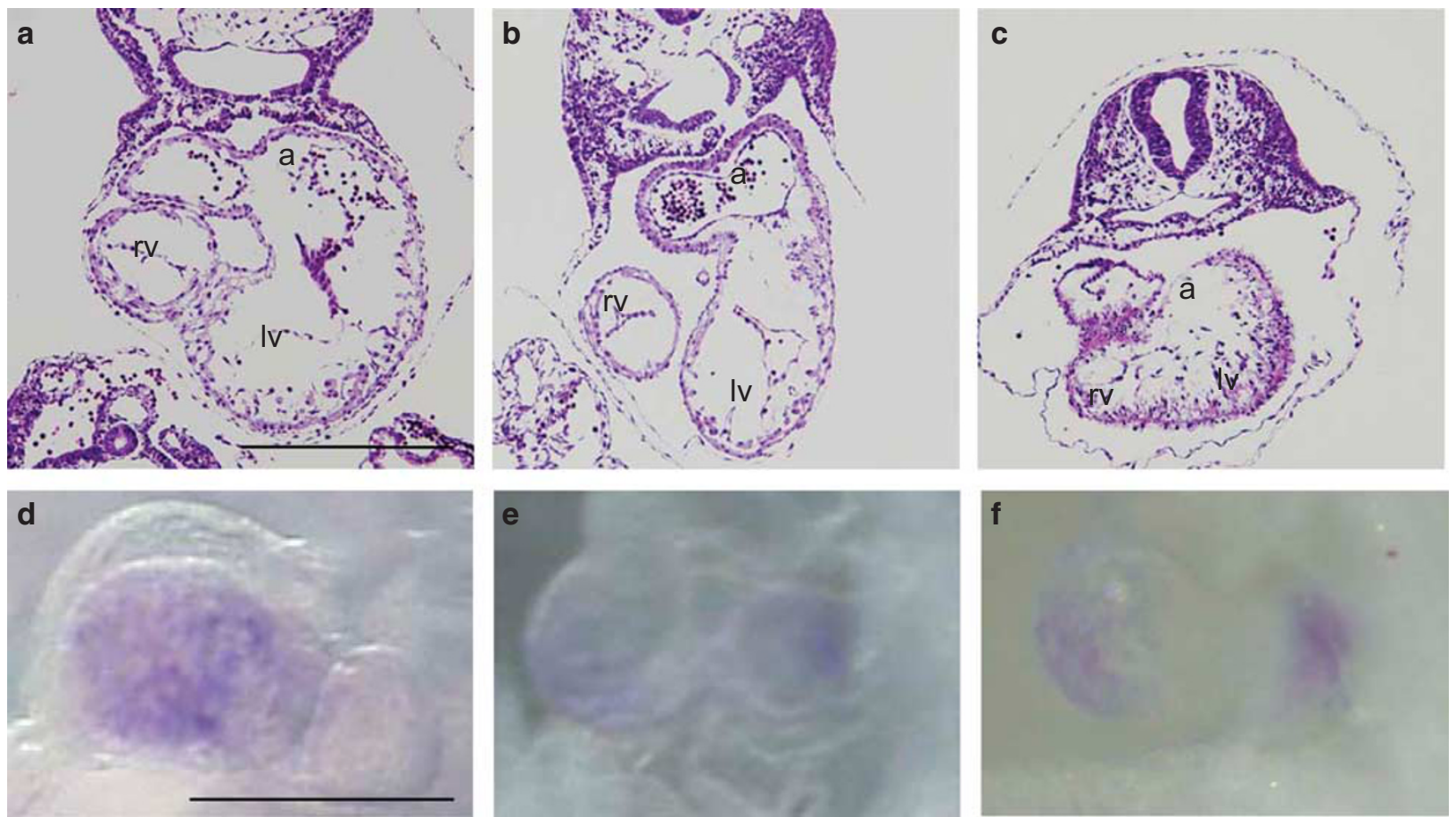

Figure 5 Cardiac malformation in ALK5 ${ }^{\mathrm{KI} / \mathrm{Kl}}$ embryo. (a-c) Transverse sections through the hearts of wild-type (a), ALK5 $5^{\mathrm{Kl} / \mathrm{KI}}$ (b), and ALK5 ${ }^{-/-}$(c) embryos at E9.5. a, atrial chamber; Iv, left ventricle; rv, right ventricle. (d-f) In situ hybridization using an antisense RNA probe coding for ANF: wild-type (d), ALK5 $5^{\mathrm{KI} / \mathrm{KI}}$ (e), and $\mathrm{ALK}^{-1-}$ (f) embryos at E9.5. We could not observe any staining using a sense RNA probe for ANF (data not shown). Scale bar: $500 \mu \mathrm{m}$. 


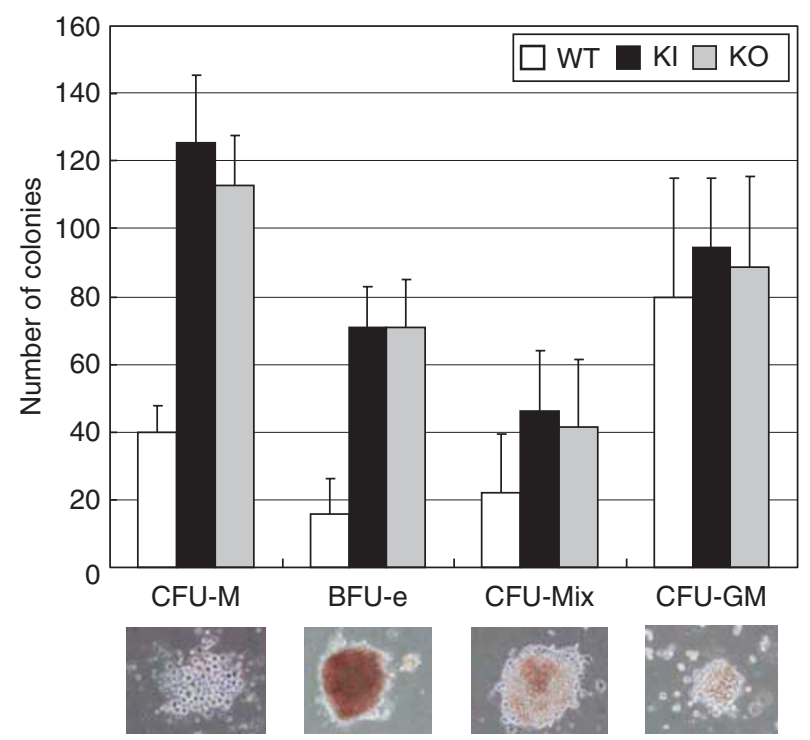

Figure 6 Preferential differentiation of hematopoietic precursors in ALK5 ${ }^{\mathrm{KI} / \mathrm{KI}}$ yolk sac to erythroid and macrophage lineages. Differentiation of hematopoietic precursors to CFU-M, BFU-e, CFU-GM, or CFU-Mix using yolk sacs at E9.5. Yolk sacs were collected from E9.5 embryos and dispersed, and equal numbers of cells were plated on methylcellulose supplemented with various cytokines. Embryos carrying 18-20 somite pairs were used in the assay. The experiments were carried out twice. The representative results are shown $(n=3)$. Photos show typical morphologies for each lineage. WT, wild-type yolk sac; $\mathrm{Kl}, \mathrm{ALK} 5^{\mathrm{KI} / \mathrm{Kl}}$ yolk sac; $\mathrm{KO}, \mathrm{ALK}^{-/-}$yolk sac; $\mathrm{CFU}$, colonyforming unit; BFU-e, burst-forming unit-erythroid; $M$, macrophage; GM, myeloid (granulocyte-macrophage); Mix, erythroid-myeloid.

and macrophage lineages in the yolk sacs of both mutants was prominent.

\section{DISCUSSION}

Embryonic development depends on the timely and correct establishment of a mature vasculature to supply oxygen and nutrients to each organ and to discard waste. We have already reported that both TGF- $\beta /$ ALK1 and TGF- $\beta /$ ALK5 signals are indispensable for vascular development, ${ }^{13,17}$ and that the kinase activity of ALK5 is required for TGF- $\beta$ signaling through ALK1. ${ }^{9}$ To further consolidate data showing a requirement of ALK5 for TGF- $\beta$ /ALK1 signaling, we generated $\mathrm{ALK} 5^{\mathrm{KI} / \mathrm{KI}}$ mice in which a mutation in ALK5 retains the ability to activate the TGF- $\beta$ /ALK1/BR-Smad signal but not the TGF- $\beta$ /ALK5/AR-Smad signal in ECs. ${ }^{9,13}$ Although we initially expected the $A L K 5^{\mathrm{KI} / \mathrm{KI}}$ mice to survive until birth because of the presence of ALK5 mutant-mediated TGF- $\beta$ / ALK1 signaling, the ALK5 ${ }^{\mathrm{KI} / \mathrm{KI}}$ mice died at E10.5-E11.5, which is comparable with the survival rate of $\mathrm{ALK}^{-1-}$ mice (Tables 1 and 2). ${ }^{9,13}$ As morphological differences between the dead embryos from the ALK5 ${ }^{\mathrm{KI} / \mathrm{KI}}$ and $\mathrm{ALK} 5^{-1-}$ mice were not obvious ${ }_{1}^{13}$ we examined the vasculature of yolk sacs from the $\mathrm{ALK} 5^{\mathrm{KI} / \mathrm{KI}}$ and $\mathrm{ALK} 5^{-1-}$ embryos in more detail. The yolk sacs from the ALK5 ${ }^{\mathrm{KI} / \mathrm{KI}}$ embryos exhibited more sprouting vessels than did those from the ALK5 ${ }^{-1-}$ embryos although the vasculature in the yolk sacs from the wild-type embryos had fully developed by E9.5. The placental phenotypes of the $\mathrm{ALK} 5^{\mathrm{K} / \mathrm{KI}}$ and $\mathrm{ALK} 5^{-/-}$embryos were also similar. Although the fetoplacental blood vessels from the $\mathrm{ALK}^{\mathrm{KI} / \mathrm{KI}}$ and $\mathrm{ALK5}^{-1-}$ mice did not branch into the spongiotrophoblast layers, a few fetoplacental vessels in the $\mathrm{ALK} 5^{\mathrm{KI} / \mathrm{KI}}$ embryos could be seen to be close to the maternal vessels. Ablation of ALK5 or ALK1 in mice has also been reported to cause abnormality in the placental vasculature. ${ }^{17,29}$ Thus, the evidence yielded by our study indicated that the mutant ALK5-mediated signal possibly rescued, albeit in small part, the defect in vessel formation in the yolk sacs and placentas from ALK5 knock-out embryos.

Overexpression of the mutant corresponding to the ALK5 knock-in allele enhances TGF- $\beta$ /ALK1/BR-Smad pathway signaling in ALK5-deficient ECs, ${ }^{8}$ whereas our results in vivo showed only subtle rescue of the phenotype seen in the $\mathrm{ALK}^{-1-}$ embryos even though phosphorylation of BR-Smad by TGF- $\beta$ in the yolk sacs could be detected. ${ }^{13}$ One explanation for why the phenotype in the $\mathrm{ALK}^{-1-}$ mice is more severe than that in the $\mathrm{ALK} 5^{\mathrm{KI} / \mathrm{KI}}$ mice might be the expression of ALK4 in ECs. ${ }^{13}$ There is a possibility that ALK4-mediated Smad2 signaling partially relieves the vascular phenotypes in ALK5 $5^{\mathrm{KI} / \mathrm{KI}}$ mice. The other possibility is that the ALK1 pathway or p38/JNK pathway activated by the mutant ALK5 in $\mathrm{ALK5}{ }^{\mathrm{KI} / \mathrm{KI}}$ embryos $^{9,16}$ is involved in its milder phenotype.

In the ALK5 ${ }^{\mathrm{KI} / \mathrm{KI}}$ mice, the ALK5/AR-Smad pathway is lacking in all cells, including in VSMCs and pericytes. VSMCs and pericytes are substantial components of the vascular structure and require the TGF- $\beta$ /ALK5/AR-Smad pathway for their motility and production of extracellular matrix proteins. ${ }^{30}$ Thus, they might not be fully recruited to ECs without TGF- $\beta$ /ALK5/AR-Smad signaling. Recently, three reports showed that TGF- $\beta$-mediated BR-Smad phosphorylation takes place through ALK5. ${ }^{31-33}$ One of the reports concluded that TGF- $\beta$-stimulated BR-Smad phosphorylation is essential for TGF- $\beta$-induced migration, whereas ALK 5 with a mutation in its L45 loop failed to restore TGF- $\beta$-induced BR-Smad phosphorylation and migration in ALK5-depleted cells. $^{32}$ Thus, VSMCs (or pericytes) in $\mathrm{ALK} 5^{\mathrm{KI} / \mathrm{KI}}$ embryos are unable to contribute to vascular formation because of their decreased motility. Consequently, the vascular structure in $\mathrm{ALK}^{\mathrm{KI} / \mathrm{KI}}$ embryos might remain immature.

Park $e t a l^{34}$ reported that deletion of either the ALK5 or T $\beta$ RII gene in ALK1-expressing cells caused no phenotype but only deletion of ALK1, resulting in severe vascular malformation in the embryo proper. They concluded that neither ALK5 nor T $\beta$ RII is required for ALK1 signaling in ECs. On the other hand, an independent study showed that EC-specific loss of the TGF- $\beta$ /ALK5/AR-Smad pathway resulted in angiogenic defects. ${ }^{13,35}$ These contradictory results might be because of different efficiencies of Cre recombinase by the ALK1 promoter in the endothelium compared with Tie1-cre as used in one study $v s$ the other. To resolve these inconsistencies, it will be necessary to compare the ability of Tie2- 
Cre (or Tie1-Cre) with that of ALK1-Cre using ALK $5^{\text {flox/flox }}$ and $\mathrm{T} \beta \mathrm{RII}^{\text {flox/flox }}$ mice directly.

A large number of erythroid and macrophage colonies in the yolk sacs from the $\mathrm{ALK} 5^{\mathrm{KI} / \mathrm{KI}}$ and $\mathrm{ALK} 5^{-1-}$ embryos were observed, whereas very few differentiated colonies of hematopoietic precursors in the para-aortic splanchnopleura and the placenta were detected (data not shown). As we reported earlier, the expression of ALK4 in the yolk sacs from the $\mathrm{ALK}^{-1-}$ embryos was higher than that from the wild-type controls and may have compensated for loss of ALK5. ${ }^{13}$ As activin is a potent inducer of erythrocyte differentiation, it is possible that activin-mediated ALK4 signaling is potentiated in yolk sacs from $\mathrm{ALK} 5^{\mathrm{KI} / \mathrm{KI}}$ and $\mathrm{ALK} 5^{-1-}$ embryos to force the hematopoietic progenitors to differentiate into erythrocytes. Otherwise, TGF- $\beta$ signaling through ALK5 and/or ALK1 might be able to restrict differentiation of hematopoietic progenitors in yolk sacs. It will be interesting to study the mechanism by which loss of TGF- $\beta$ signaling potentiates differentiation of hematopoietic progenitors to either erythrocytes or macrophages in yolk sacs.

In summary, our results indicate that the ALK5-mediated TGF- $\beta$ /ALK1/BR-Smad pathway in ECs is not sufficient for mature vessel formation in embryos. Both ECs and VSMCs (or pericytes) might require the TGF- $\beta$ /ALK5/AR-Smad pathway to complete maturation of blood vessels. In addition, TGF- $\beta$ signaling is possibly needed for well-balanced differentiation of hematopoietic progenitors.

Supplementary Information accompanies the paper on the Laboratory Investigation website (http://www.laboratoryinvestigation.org)

\section{ACKNOWLEDGEMENTS}

This research was supported by Grants-in-aid for Scientific Research (M K and $\mathrm{S} \mathrm{I);} \mathrm{a} \mathrm{grant} \mathrm{of} \mathrm{the} \mathrm{Genome} \mathrm{Network} \mathrm{Project} \mathrm{from} \mathrm{the} \mathrm{Ministry} \mathrm{of}$ Education, Culture, Sports, Science, and Technology (M K); a Grant-in-Aid for JSPS Fellows from the Japan Society for the Promotion of Science (F I); the University of Tsukuba Research Project (M K); an AstraZeneca Research Grant 2004 (S I); the Kowa Life Science Foundation (S I.); the Kato Memorial Bioscience Foundation (S I); and the Dutch Cancer Society and EC sixth framework STREP Tumor-Host Genomics (P t-D). We thank Drs E Dzierzak and T Yokomizo for valuable advice and Dr F Miyamasu for excellent English proofreading.

\section{DISCLOSURES}

The authors declare no competing financial interests.

1. Carmeliet P. Angiogenesis in life, disease and medicine. Nature 2006:438:932-936.

2. Adams RH, Alitalo K. Molecular regulation of angiogenesis and lymphangiogenesis. Nat Rev Mol Cell Biol 2007;8:464-478.

3. Massagué J, Blain SW, Lo RS. TGF $\beta$ signaling in growth control, cancer, and heritable disorders. Cell 2000;103:295-309.

4. Gordon KJ, Blobe GC. Role of transforming growth factor- $\beta$ superfamily signaling pathways in human disease. Biochim Biophys Acta 2008; 1782:197-228.

5. Heldin CH. TGF- $\beta$ signalling from receptor to Smads. In: Derynck $\mathrm{R}$ Miyazono K (eds). The TGF- $\beta$ family. Cold Spring Harbor Laboratory Press: New York, NY, 2008, pp 259-286.

6. ten Dijke P, Hill CS. New insights into TGF- $\beta$-Smad signalling. Trends Biochem Sci 2004;29:265-273.
7. Massagué J, Seoane J, Wotton D. Smad transcription factors. Genes Dev 2005;19:2783-2810.

8. Goumans MJ, Valdimarsdottir $\mathrm{G}$, Itoh $\mathrm{S}$, et al. Balancing the activation state of the endothelium via two distinct TGF- $\beta$ type I receptors. EMBO J 2002;21:1743-1753.

9. Goumans MJ, Valdimarsdottir $G$, Itoh $S$, et al. Activin receptor-like kinase (ALK) 1 is an antagonistic mediator of lateral TGF $\beta /$ ALK5 signaling. Mol Cell 2003;12:817-828.

10. David L, Mallet C, Mazerbourg S, et al. Identification of BMP9 and BMP10 as functional activators of the orphan activin receptor-like kinase 1 (ALK1) in endothelial cells. Blood 2007;109:1953-1961.

11. Scharpfenecker $M$, van Dinther M, Liu Z, et al. BMP-9 signals via ALK1 and inhibits bFGF-induced endothelial cell proliferation and VEGFstimulated angiogenesis. J Cell Sci 2007;120:964-972.

12. Goumans MJ, Lebrin F, Valdimarsdottir G. Controlling the angiogenic switch: a balance between two distinct TGF- $\beta$ receptor signaling pathways. Trends Cardiovasc Med 2003;13:301-307.

13. Carvalho RLC, Itoh F, Goumans MJ, et al. Compensatory signalling induced in the yolk sac vasculature by deletion of $\operatorname{TGF} \beta$ receptors in mice. J Cell Sci 2007;120:4269-4277.

14. Chen YG, Hata A, Lo RS, et al. Determinants of specificity in TGF- $\beta$ signal transduction. Genes Dev 1998;12:2144-2152.

15. Persson $\mathrm{U}$, Izumi $\mathrm{H}$, Souchelnytskyi $\mathrm{S}$, et al. The $\mathrm{L} 45$ loop in type I receptors for TGF- $\beta$ family members is a critical determinant in specifying Smad isoform activation. FEBS Lett 1998;434:83-87.

16. Itoh $S$, Thorikay M, Kowanetz $M$, et al. Elucidation of Smad requirement in transforming growth factor- $\beta$ type I receptor-induced responses. J Biol Chem 2003;278:3751-3761.

17. Larsson J, Goumans MJ, Sjostrand $\sqcup$, et al. Abnormal angiogenesis but intact hematopoietic potential in TGF- $\beta$ type I receptor-deficient mice. EMBO J 2001;20:1663-1673.

18. Shi $\mathrm{L}$, Itoh $\mathrm{F}$, Itoh $\mathrm{S}$, et al. Ephrin-A1 promotes the malignant progression of intestinal tumors in $\mathrm{Apc},(\mathrm{min} /+) \mathrm{min} /+$ mice. Oncogene 2008;27:3265-3273.

19. Ema $M$, Yokomizo $T$, Wakamatsu $A$, et al. Primitive erythropoiesis from mesodermal precursors expressing VE-cadherin, PECAM-1, Tie2, endoglin, and CD34 in the mouse embryo. Blood 2006;108:4018-4024.

20. Wilkinson DG, Nieto MA. Detection of messenger RNA by in situ hybridization to tissue sections and whole mounts. Methods Enzymol 1993;225:361-373.

21. Hosoya-Ohmura S, Mochizuki N, Suzuki M, et al. GATA-4 incompletely substitutes for GATA-1 in promoting both primitive and definitive erythropoiesis in vivo. J Biol Chem 2006;281:32820-32830.

22. Palis J, Robertson $S$, Kennedy $M$, et al. Development of erythroid and myeloid progenitors in the yolk sac and embryo proper of the mouse. Development 1999;126:5073-5084.

23. Ferkowicz MJ, Yoder MC. Blood island formation: longstanding observations and modern interpretations. Exp Hematol 2005;33: 1041-1047.

24. Goumans MJ, Mummery C. Functional analysis of the TGF $\beta$ receptor/ Smad pathway through gene ablation in mice. Int J Dev Biol 2000;44:253-265.

25. Rossant J, Cross JC. Placental development: lessons from mouse mutants. Nat Rev Genet 2001;2:538-548.

26. Fishman MC, Olson EN. Parsing the heart: genetic modules for organ assembly. Cell 1997;91:153-156.

27. Durocher $\mathrm{D}$, Charron $\mathrm{F}$, Warren $\mathrm{R}$, et al. The cardiac transcription factors Nkx2-5 and GATA-4 are mutual cofactors. EMBO J 1997;6:5687-5696.

28. Lee $\mathrm{Y}$, Shioi T, Kasahara $\mathrm{H}$, et al. The cardiac tissue-restricted homeobox protein Csx/Nkx2.5 physically associates with the zinc finger protein GATA4 and cooperatively activates atrial natriuretic factor gene expression. Mol Cell Biol 1998;18: 3120-3129.

29. Hong KH, Seki T, Oh SP. Activin receptor-like kinase 1 is essential for placental vascular development in mice. Lab Invest 2007;87: 670-679.

30. Verrecchia $\mathrm{F}$, Mauviel A. Transforming growth factor- $\beta$ signaling through the Smad pathway: role in extracellular matrix gene expression and regulation. J Invest Dermatol 2002;118:211-215.

31. Daly AC, Randall RA, Hill CS. Transforming growth factor $\beta$-induced Smad1/5 phosphorylation in epithelial cells is mediated by novel receptor complexes and is essential for anchorageindependent growth. Mol Cell Biol 2008;28:6889-6902. 
32. Liu IM, Schilling $\mathrm{SH}$, Knouse KA, et al. TGF $\beta$-stimulated Smad1/5 phosphorylation requires the ALK5 L45 loop and mediates the pro-migratory TGF $\beta$ switch. EMBO J 2009;28:88-98.

33. Wrighton $\mathrm{KH}$, Lin $\mathrm{X}, \mathrm{Yu} \mathrm{PB}$, et al. TGF $\beta$ can stimulate Smad1 phosphorylation independently of BMP receptors. J Biol Chem 2009;284:9755-9763.
34. Park SO, Lee YJ, Seki T, et al. ALK5- and TGFBR2-independent role of ALK1 in the pathogenesis of hereditary hemorrhagic telangiectasia type 2. Blood 2008;111:633-642.

35. Jiao K, Langworthy $M$, Batts $L$, et al. Tgf $\beta$ signaling is required for atrioventricular cushion mesenchyme remodeling during in vivo cardiac development. Development 2006;133:4585-4593. 